Wright State University

From the SelectedWorks of Sirisha C. Naidu

2016

Social Reproduction and the Agrarian Question of Women's Labour in India

Sirisha C Naidu, Wright State University 


\title{
Social reproduction and the agrarian question of women's labour in India
}

Authors: Sirisha C. Naidu and Lyn Ossome

Affiliation: Sirisha C. Naidu is Associate Professor in the Department of Economics at Wright State University, USA; Lyn Ossome is Research Fellow at Makerere Institute of Social Research (MISR), Uganda

Emails: sirisha.naidu@wright.edu, 1yn.ossome@gmail.com

Forthcoming: Agrarian South: Journal of Political Economy, 5(1) 2016.

\begin{abstract}
Using a social reproduction framework, this article explores how reproduction of rural working class households is rearticulated to capitalist production in India. Our analysis of the conditions in India reveals that the interaction of three institutions - market, state, and household - has imposed the burden of reproduction on women. In turn, women's work is dependent on private and common lands. This link, between the role of women's unpaid labour in reproducing rural households and the fact that this work remains largely dependent on land, constitutes a failure of the Indian economy to provide decent livelihoods. It also reasserts gender equity as a contemporary and unresolved question in the midst of India's agrarian transition and underscores the importance of instituting agrarian reforms and state intervention at levels sufficient for social reproduction.
\end{abstract}

Key words: Social reproduction; gender; land and labour; domestic economies; India 


\section{Introduction}

Land reforms have been viewed as crucial to economic development by some and have long constituted an integral aspect of radical political demands. ${ }^{1}$ According to this rationale, land reforms would stimulate agricultural production, which, in turn, would facilitate accumulation required for industrialization without undercutting investments in agriculture or the standard of living of the working classes. However, the failure of land reforms in India, as well as a stagnating agrarian economy, does not appear to have an impact on economic growth or capital accumulation in the country, nor has the latter benefited all sections of society. To illustrate, in the period between 1990-91 and 2004-05, the Annual Survey of Industries reports that the total value of output in India increased by 518 percent and profits by 110 percent (Jha, 2009). Yet, in this same period of phenomenal growth and profits, the total wage bill, including social security, only increased by 240 percent (Jha, 2009), while in 1997-2008 the number of farmer suicides recorded in India was 199,132 (Sainath, 2010). These developments pose questions regarding the continued relevance of land for the rural economy.

While agriculture only contributes to 18 percent of value added in GDP, it continues to support about 47 percent of total employment (WDI, 2014). It is of significant concern that the nonagricultural economy has created insufficient employment to absorb the relative surplus population. The attrition of private and common lands by land grabs, competition from international markets, and the globalized regime of flexible and precarious immobile labour but mobile capital have, together, deepened the impact of the parallel process of withdrawal of the Indian state from agricultural investment and protection of the working classes. The state has intervened in some social welfare programmes, but these appear to be half-hearted attempts to assuage the increasingly immiserated population and retain its legitimacy as a democratic entity that exists in the interests of all classes.

Our objective in this paper is not to provide a discussion of economic growth, nor of the effect of land on capital. Rather, we are interested in the conditions under which the rural poor reproduce

\footnotetext{
${ }^{1}$ We thank participants of the 2016 AIAS/Agrarian South Summer School and two anonymous reviewers for their thoughtful comments and suggestions. The usual disclaimer applies.
} 
themselves. Social reproduction would broadly include biological reproduction, everyday survival, accumulation of education and skills to participate in the capitalist economy (for workers' participation in the formal and informal labour market), acquisition of skills to ensure the survival of the households (i.e., skills to engage in household production and care work) and inculcating the necessary value system to ensure the reproduction of the patriarchal and capitalist economy. We adopt a more basic definition of daily reproduction of working class households through the acquisition and provision of such basic needs as food, shelter, clothing, and healthcare (Katz, 2001).

Social reproduction in contemporary capitalist economies hinges on the interplay between three major institutions: households, markets, and the state (Antonopolous \& Hirway, 2010; Dickinson \& Russell, 1985). The roles that these institutions play in ensuring social reproduction may both contradict and complement each other. In addition, we also adopt Rosa Luxemburg's (1951) insights that non-capitalist forms of production are essential for capitalism even if the latter is waged in a continuous struggle to undermine the former. Non-capitalist social formations of household and family labour, specifically articulated to peasant modes of production, include unpaid labour that directly benefits the market, as well as unpaid and invisible domestic productive and reproductive labour. The latter supports the reproduction of the working classes and the reserve army of labour, thus reproducing the costs to capitalism of supporting a labour pool. The incursion of capital and consumer goods in rural areas and the dispossession that accompanies commodification forces rural populations to purchase from the market what they used to produce for themselves. The accompanying shrinking of the non-capitalist strata means that some rural households cannot keep up with the socially determined level of consumption, thus lowering the living standards of all workers. However, capitalism does not benefit from the complete destruction of non-capitalist economies, as it would lead to a 'standstill of accumulation' (Luxemburg, 1951).

Economic changes since the 1980s have simultaneously differentiated and homogenized the conditions of capitalist exploitation and, hence, the conditions under which rural households reproduce. Rural households are engaged in various instances of work, including urban and rural, agricultural and non-agricultural, wage employment and self-employment, and significantly for 
this study, self-exploitative non-capitalist production. We do not relate these activities only with petty-commodity production, but rather with the reliance of rural dwellers on different livelihood strategies and wage work that does not free them from their peasant roots. We use an assemblage of data from various sources to present our central argument, that due to the insufficiency of this cornucopia of livelihood strategies, the satisfaction of the minimum consumption levels of rural households and their very reproduction is critically dependent on women's labour, which is, in turn, articulated to the agrarian question of land. While state intervention in India provides some succour, subsistence production, care work, and other forms of non-capitalist production support the reproduction of the working classes, thereby subsidizing capitalist production. In turn, these work activities, which are often, but not exclusively, carried out by women, are dependent on private and common land. Land, therefore, does not assume significance only due to the semiproletarian condition, but also because the capitalist market economy does not support the reproduction of the working classes (Moyo \& Yeros, 2005). Under changed global economic conditions, land is unlikely to lift working classes out of poverty. Nevertheless, reproduction of rural working class households depends on land and women's labour, which, in turn, portends continued immiseration and deepens the contradictions of achieving gender equity under conditions of capitalism. Political demands for land and agrarian reform therefore should address the gender inequities underlying women's invisible work.

Our approach to this analysis is feminist political economy, through which we conceptualise the various forms of women's labour as being dialectically linked to changes in the agrarian structure of society. Social change in rural India not only differs from the path predicted by the classical agrarian question, but it has also been fraught with significant diversity across the country (Shah \& Harris-White, 2011). In their bid to theorize and understand the changes, researchers have relied on a variety of methodological approaches. Some have relied on case studies involving longitudinal researchor in new areas, whereas others focus on general formulations (ibid). This study falls in the latter category, not as an attempt to homogenize, but to develop a structural position on the basis of national-level data. We view the existence and continuation of women's reproductive unpaid labour as a continuation of capitalism's tendency to produce and exploit noncapitalist forms of production. In this article, we show the agrarian question of labour as being not only deeply gendered, but also highly differentiated by the social relations present in various 
spheres of the production of labour under neoliberalism. This differentiation would explain, too, the wide variations of labouring conditions by region in India - but such analysis is beyond the scope of this paper.

\section{Market economy, land and reproduction}

The wage economy facilitates reproduction of workers and their families, as wages are transformed into means of subsistence. Yet even though reproduction of labour power is a precondition for the reproduction of capital, it is not integral to the sphere of surplus value production. The delinking of the cycles of social reproduction and capital accumulation, especially under neoliberal capitalism, leads to social fragmentation and births new (or deepens existing) contractions (Mingione, 1985). In this section, we explore the conditions of reproduction in rural India that are fostered by the capitalist market economy.

Structural transformation in the Indian economy, despite being stunted, has been accompanied by increasing landlessness. The share of agriculture in value-added GDP dropped from 28 to 18.7 percent in 1994-2012, whereas the share of employment decreased from 61 to 47 percent in the same period (WDI, 2014). Nearly 64 percent of all rural households own less than 0.41 hectares (that is, less than one acre) of land, this being the group that Basole and Basu (2011) characterize as 'effectively landless'. Table 1 indicates that even though only 16 percent of rural households owned less than 0.005 hectares in 2011-12, 48 percent of all rural households cultivated less than 0.005 hectares.

Table 1: Distribution of rural households by land-size categories, 2011-12

\begin{tabular}{|l|l|l|l|l|l|l|}
\hline $\begin{array}{l}\text { Land in } \\
\text { hectares }\end{array}$ & $<0.004$ & $0.005-0.4$ & $0.41-1.00$ & $1.01-2$ & $2.01-4.00$ & $>4.01$ \\
\hline \multicolumn{7}{|c|}{ Distribution of households (\%) } \\
\hline $\begin{array}{l}\text { by land } \\
\text { cultivated }\end{array}$ & 48 & 19.8 & 14.2 & 10.3 & 5.4 & 2.4 \\
\hline $\begin{array}{l}\text { by land } \\
\text { owned }\end{array}$ & 15.5 & 48 & 16.7 & 10.9 & 6.3 & 2.7 \\
\hline
\end{tabular}

Source: NSSO (2014a). 
Table 2 compares the proportion of income derived from various sources, total income, and consumption expenditure for rural households in 2003 and 2012-13. It indicates that the 'effectively landless' households derived between 41 and less than one percent of their total household income from agriculture. This suggests that agriculture alone may not be a viable strategy for a large proportion of rural households and that dependence on agricultural income varies even among the land-poor households. However, while agriculture is not the sole source of income, neither is wage income. 'Effectively landless' households derived 38 to 64 percent of total household income from wages in 2012-13, thus hinting at a high degree of semi-proletarianization. Table 2 suggests that 'effectively landless' households are engaged in diverse livelihoods, including casual (agricultural and non-agricultural) labour and agricultural and non-agricultural self-employment (see also NSSO, 2014a). These data imply that although de-peasantization is presently a key feature of the rural Indian economy, it is neither a stable nor linear process, as peasant modes of production remain necessary for the survival of rural households.

Furthermore, striking differences between income sources in 2003 and 2012-13 illustrate, in Table 2, the critical importance of land for sustaining households. Higher landholdings are positively associated with the proportion of household income derived from agriculture and higher total incomes, but negatively associated with the proportion of household income derived from wage income. For households with landholdings above 0.41 hectares, agriculture contributed between 57 and 86 percent of total household income in 2012-13.

For land-rich households (with landholdings above 4.01 ha), the proportion of income received from cultivation remains almost constant at 86 percent in 2003-13. While total household consumption expenditure for this section of rural society nearly doubled between 2003 and 201213 (from Rs. 6,418 to Rs. 14,447), net income increased nearly eightfold in the same period, from Rs. 3,249 to Rs. 26,941. Similar to land-rich households, total household consumption expenditure for households with the lowest landholdings (less than 0.001 ha) nearly doubled between 2003 and 2012-13, from Rs. 2,997 to Rs. 5,108. However, unlike the land-rich, total household income of land-poor households only tripled in the same period, from Rs. 1,380 to Rs. 4,561.

Table 2: Proportion of income from various sources, consumption expenditure and net investment per household and household deficit (2003 and 2012-13) 


\begin{tabular}{|c|c|c|c|c|c|c|c|}
\hline \multirow{2}{*}{$\begin{array}{l}\text { Size class } \\
\text { of land } \\
\text { possessed } \\
\text { in hectares }\end{array}$} & \multicolumn{4}{|c|}{ Proportion of income from } & \multirow[b]{2}{*}{$\begin{array}{l}\text { Total } \\
\text { income } \\
\text { (Rs.) }\end{array}$} & \multirow[b]{2}{*}{\begin{tabular}{|l} 
Total \\
consumption \\
expenditure \\
(Rs.)
\end{tabular}} & \multirow{2}{*}{$\begin{array}{l}\text { Net income = } \\
\text { total income } \\
\text { less } \\
\text { expenditure } \\
\text { (Rs.) }\end{array}$} \\
\hline & Wages & $\begin{array}{l}\text { receipt } \\
\text { from } \\
\text { cultivation }\end{array}$ & $\begin{array}{l}\text { Animal } \\
\text { farming }\end{array}$ & $\begin{array}{l}\text { Non- } \\
\text { farm } \\
\text { business }\end{array}$ & & & \\
\hline & \multicolumn{7}{|c|}{ 2012-13 } \\
\hline$<0.001$ & 63.63 & 0.66 & 25.89 & 9.80 & 4561 & 5108 & -547 \\
\hline $\begin{array}{l}0.001- \\
0.004\end{array}$ & 57.47 & 16.55 & 14.96 & 11.05 & 4152 & 5401 & -1249 \\
\hline $0.005-0.4$ & 38.33 & 40.88 & 11.99 & 8.81 & 5247 & 6020 & -773 \\
\hline $0.41-1$ & 23.52 & 57.28 & 11.13 & 8.07 & 7348 & 6457 & 891 \\
\hline $1.01-2$ & 15.44 & 68.58 & 10.82 & 5.16 & 10730 & 7786 & 2944 \\
\hline $2.01-4$ & 10.34 & 77.62 & 7.64 & 4.38 & 19637 & 10104 & 9533 \\
\hline$>=4.01$ & 3.17 & 86.22 & 6.34 & 4.28 & 41388 & 14447 & 26941 \\
\hline \multirow[t]{2}{*}{ All } & 32.23 & 47.95 & 11.87 & 7.97 & 6426 & 6223 & 203 \\
\hline & \multicolumn{7}{|l|}{2003} \\
\hline$<0.001$ & 77.90 & 0.80 & 4.64 & 16.67 & 1380 & 2297 & -917 \\
\hline $\begin{array}{l}0.001- \\
0.004 \\
\end{array}$ & 59.58 & 18.13 & 5.76 & 16.53 & 1633 & 2390 & -757 \\
\hline $0.005-0.4$ & 39.80 & 43.34 & 6.19 & 10.67 & 1809 & 2672 & -863 \\
\hline $0.41-1$ & 25.47 & 63.30 & 4.09 & 7.14 & 2493 & 3148 & -655 \\
\hline $1.01-2$ & 17.75 & 74.81 & 1.59 & 5.85 & 3589 & 3685 & -96 \\
\hline $2.01-4$ & 8.55 & 82.31 & 0.21 & 8.92 & 5681 & 4626 & 1055 \\
\hline$>=4.01$ & 5.76 & 86.08 & 1.17 & 6.99 & 9667 & 6418 & 3249 \\
\hline All & 38.72 & 45.82 & 4.30 & 11.16 & 2115 & 2770 & -655 \\
\hline
\end{tabular}

Source: NSSO (2005, 2014b); authors' calculations.

In 2003, households cultivating less than two hectares of land suffered an income deficit, which could be explained by the agrarian crisis in the early part of the twenty-first century. However, ten years later, in 2012-13, after the worst of the crisis, effectively landless households (with less than $0.41 \mathrm{ha}$ ) continued to face a deficit, ranging from 10 to 30 percent of total income. A simple ratio of consumption expenditure in the highest and lowest land categories increased marginally in 2003-13, from 2.79 to 2.82. However, the ratio of income for the highest and lowest land cultivating categories increased from 7.01 to 9.07, in the same period. Thus, relative inequalities in consumption expenditures have not varied much over this 10-year period, possibly because consumption patterns tend to be relatively smooth (Vakulabharanam, 2010), but relative inequality in income has increased. 
We make three related observations based on these data. First, while some may view the diversity of livelihoods as an accumulative strategy, the income deficit faced by land-poor households suggests the necessity of these livelihoods for the reproduction of rural working class households (see also Shah \& Harris-White, 2011). Second, land continues to be important in that it is associated with higher net incomes. For those with lower landholdings, land may not constitute an accumulative strategy or even a path out of poverty. Nevertheless, it potentially contributes to reproduction (see also Moyo, Jha \& Yeros, 2013). Third, it appears that income from market engagement, which includes self-employment in agriculture and non-farm business and wage labour, is insufficient for maintaining consumption and, hence, reproduction. As a result, we hypothesize that land-poor households are able to sustain income deficits either due to state intervention, non-capitalist production in the form of subsistence production, or remittances, though we do not explore the issue of remittances in this paper.

\section{State intervention in reproduction}

As a precondition to capitalist production, reproduction of the working classes constitutes the 'faux frais' of capitalist production (Marx, 1986: 603). Wages constitute the 'first form of proletarian subsistence', but its adequacy in the processes of 'self-managed reproduction' depends on workers' access to employment and decent wages (Dickinson \& Russell, 1985). To manage the contradictions associated with a reproduction crisis, the state may intervene to prevent or mitigate cost-shifting by capitalists through appropriate legislations, or may seek to underwrite some or most of reproductive costs. The actual articulation and effective implementation of these interventions, however, is historical and dependent on the social structure and the growth process (ibid).

The Indian welfare regime ${ }^{2}$ since the 1980 s has increasingly intervened only to the extent of correcting market failures or failures of family provisioning, by providing meagre support to

\footnotetext{
2 We follow Gough's (2004) analytical distinction regarding state welfare provision between 'welfare regimes' and 'welfare state' regimes, to differentiate between the role and scale of state welfare provision in countries of the Global North and South.
} 
'deserving' households (Palriwala \& Neetha 2009). The intervention has been haphazard and piecemeal (Gough, 2004), and has complemented the systematic gutting of the welfare regime (Ahmed \& Chatterjee 2013) to create a neoliberal state even more sensitive to the needs of the capitalist economy. We focus our analysis in this section on two specific welfare programmes, the National Rural Employment Guarantee Scheme (NREGS) and the Public Distribution System (PDS), to illustrate the (inadequate) role of the Indian state in reproducing the household, and at the same time, the tensions that exist in the provision and the coverage of these programmes.

The PDS system, which was initially restricted to urban households during World War II, was extended to the entire country in post-colonial India as the joint responsibility of the federal and state governments. The system provisions basic needs items at government-mandated fixed prices through 'fair price' shops to ration cardholders. At the end of the last decade, there were about 478,000 such shops in the country (Palriwala \& Neetha, 2009). By some reports, the PDS has the highest recognition and participation of different government programmes (Dev, 2008, cited in Palriwala \& Neetha 2009). However, after liberalization, the emphasis shifted from universal coverage to one of targeting households living below the poverty line for differential pricing. Targeting has been necessitated by the declining share of food subsidy in government expenditure and GDP. This has led to the exclusion of many households that should benefit from lower prices and has fostered an environment of patronage and corruption (Palriwala \& Neetha, 2009).

The Food Security Act (2013) further erodes this programme by allowing individual states the discretionary provision to move from a targeted PDS to a cash transfer (CT) system. But CT is unlikely to alleviate food insecurity and poverty, as the programme does not address the problem of inflation indexing, the effects of volatile food prices, lack of access to cash due to poor banking networks, and the collapse of minimum support prices to farmers, who might be compelled to move away from food production or agriculture due to global competition (Ahmed \& Chatterjee, 2013: 91). Further, in the absence of decent affordable public health and education systems, CTs in India may not tackle the problem of a food budget squeeze that has potentially caused a decline in calorie consumption in India (see Basole \& Basu 2012; Ghosh, 2011; Patnaik, 2003), and will significantly affect the effectively landless and unemployed households. 
The other significant programme legislated in the last decade is the NREGS. ${ }^{3}$ An important aspect of NREGS is that, unlike past public works programmes, it implicitly accepts that the problem of under-consumption is endemic and is not restricted only to times of natural disasters (Palriwala \& Neetha, 2009). Also, unlike targeted PDS, it is open to all rural households. Beginning with the poorest 200 districts, NREGS became a nationwide program in April 2008 (Jha \& Gaiha, 2012), and remains the largest social welfare programme in India, with a budget of about USD 7 billion per year (Chopra, 2014).

With a significant proportion of households facing an income deficit (Table 2), income derived from NREGS could form an important basis of survival for the land-poor. Case studies, however, suggest varied impacts and implementation of NREGS across states. In states where it has been implemented well, the impact has been significant. It has reportedly improved food security in some parts of Central India and erstwhile Andhra Pradesh (Khera \& Nayak, 2011; Ravi \& Engler, 2013). Further, studies have reported that a high proportion of NREGS income is spent on food, medical expenses, and education (Dreze \& Khera, 2009; Pankaj, 2008; Joshi, Singh \& Joshi, 2008; Ravi \& Engler, 2013). The greatest employment beneficiaries were those from lower castes, landless households, casual agricultural workers, and households in the lowest consumption quintile; women benefited significantly from this scheme, although there is considerable inter-state variation (Dutta et al., 2012; Dreze \& Khera, 2009; Pankaj, 2008; Pankaj \& Tankha, 2009). Thus, NREGS work has been important in reproducing working class households, and has the potential to benefit the significant proportion of land-poor working class households facing income deficits, as indicated in Table 2.

Yet, despite its tremendous potential, the programme has been unable to fulfil unmet demand for work. The average number of person-days worked among households in the poorest consumption quintile participating in NREGS was 33.7 days in 2009-10, compared to the 100 days provision (Dutta et al., 2012). The mean percentage of households that completed 100 days of work in 200910 was a dismal three percent (Jha \& Gaiha 2012). Furthermore, as with other welfare policies,

\footnotetext{
${ }^{3}$ The NREGS is a public works programme that guarantees 100 days of employment a year as a right to at least one member of any rural household who is willing to perform unskilled labour at the statutory minimum wage for the program. Provisions in the Act mandate that at least one-third of the workers should be women.
} 
there have been numerous calls by the economic elite to reduce state support for NREGS. It is telling that the combined expenditure on labour and employment by the federal and state governments fell from 0.51 percent of total development and non-development expenditures in 1990-91 to less than 0.4 percent since 2000-01, even after the implementation of NREGS (RBI 2005, 2015).

The effect of India's contradictory economic policies is visible in its undertaking to strengthen welfare through NREGS and targeted PDS and CTs, despite an overarching neoliberal mode of socio-economic regulation. The policies suggest that the state recognizes the need for cushioning against the current accumulation regime. However, rather than inducing social transformation and reducing inequality, the state has limited itself to meagre attempts to reduce poverty, and focused on narrow objectives of economic growth and higher labour flexibilization (Palriwala \& Neetha, 2009). State intervention within a capitalist logic or structure - even when seemingly pro-poor inevitably functions to maintain the dynamism of capitalist accumulation (Ahmed \& Chatterjee, 2013 , p. 87), especially when capital's accumulation of political power is greater than that of the labouring classes. The Indian state in this context has not adequately fulfilled its social provisioning role. State intervention is deemed necessary only when families are incapable of adequately fulfilling this role, and increasingly even this intervention is geared towards 'individualization of social costs' (Braedley, 2006, p. 216).

\section{Households, women's work and reproduction}

The family-household constitutes another major institution of reproduction. It undertakes the conversion of wages (and social grants) into necessities of life for individual consumption, and engages in consumption of simple-use values (Dickinson \& Russell, 1985). The persistence of economic insecurity in the absence of adequate wages and state intervention also forces working class households to engage in subsistence production or 'domestic economies' (Meillassoux, 1977, cited in Cockcroft, 1983) to ensure survival. Labour expended in these activities constitute reproductive work that is often, but not exclusively, the bastion of women's invisible work. The existence and persistence of 'domestic economies' particularly allows capitalists to expect the reproduction of labour in the absence of a living wage and inadequate social welfare programmes. 
Consequently, non-capitalist social formations of household and family labour shoulder a large proportion of the burden of meeting minimum consumption levels essential for daily and generational reproduction, and as Luxemburg (1951) suggests, continues to subsidize capital accumulation.

Table 3 below provides data on the participation of female rural workers in India in various activities, from 1983 to 2011-12. It indicates an increase in women's participation in 'all domestic' activities, from 27.3 to 42.2 percent between 1987-88 and 2011-12. Correspondingly, the women's labour force participation rate (LFPR) has declined from 42.5 to 18 percent in the same period. Some have attributed this trend to an 'income effect', in which higher household incomes afford women the choice and luxury to withdraw from the labour market and produce goods that would enhance the social 'status' of the household (Abraham, 2013). This argument is, however, unconvincing.

First, the country is suffering from a lack of adequate employment creation for women workers. A closer look at the components that make up the LFPR (Table 3) reveals that its decline stems from a secular decrease in the proportion of women engaged in self-employed and unpaid work in family enterprises, as well as casual wage work, from 1987-88 to 2011-12. ${ }^{4}$ To contextualize this decline, it is important to note that in the period 2004-05 to 2011-12, when economic growth was fairly high, approximately 30.3 million agricultural workers withdrew their labour in rural India, of which 24.6 million (81.2 percent) were women (Thomas, 2014). In the same period, 25.7 million jobs were created in the non-agricultural sector in rural India, but only 4.6 million of these (17.9 percent) were for women; the total female labour force consequently shrank by 20.5 million (Thomas, 2014). Further, Kannan and Raveendran (2012) note that, of the total 28.16 million women missing from the Indian labour force in 2010, 61 percent were from the poorest households, thus challenging the 'income effect' explanation. Other studies instead attribute the decline in women's LFPR to agrarian change (Mukherjee, 2011), lack of sufficient well-paid jobs (Das, 2006), or the composition of growth rather than growth itself (Lahoti \& Swaminathan, 2013).

\footnotetext{
${ }^{4}$ It should be noted, however, that remuneration is less than desirable in these kinds of work and women tend to extend themselves physically and mentally, especially when self-employed or working in family enterprises. In the rural areas, both categories of work are primarily agricultural.
} 
Table 3: Female usual activity status distribution (for all ages), 1983-2012

\begin{tabular}{|c|c|c|c|c|c|c|c|}
\hline \multirow[b]{2}{*}{ Activity status (PS) } & \multicolumn{7}{|c|}{ Rural } \\
\hline & 1983 & $1987-88$ & $1993-94$ & $1999-2000$ & $2004-05$ & $2009-10$ & 2011-12 \\
\hline $\begin{array}{l}\text { Self-employed \& unpaid } \\
\text { family worker(1) }\end{array}$ & 21 & 22 & 18.5 & 11.4 & 13.6 & 10.2 & 9.4 \\
\hline Regular wage work (2) & 1.6 & 2.1 & 1.3 & 0.9 & 1.2 & 1.1 & 1.3 \\
\hline Casual wage work (3) & 18 & 17 & 17 & 11 & 9 & 9 & 6.8 \\
\hline All Domestic (4) & 29.8 & 27.3 & 34.4 & 36.3 & 35.5 & 39.9 & 42.2 \\
\hline domestic duties only (4a) & 15.9 & 15.1 & 15.7 & 20.3 & 17.5 & 22 & 18.5 \\
\hline $\begin{array}{l}\text { Domestic duties \& allied } \\
\text { activities (4b) }\end{array}$ & 13.9 & 12.2 & 18.7 & 16 & 18 & 17.9 & 23.7 \\
\hline Unemployed (5) & 0.6 & 1.4 & 0.5 & 0 & 0.8 & 0.5 & 0.5 \\
\hline Education (6) & 7.6 & 7.2 & 11.7 & 18.4 & 21.3 & 23.8 & 25.1 \\
\hline Others (7) & 21.4 & 23.1 & 16.2 & 22.4 & 18.4 & 15.6 & 14.7 \\
\hline "WPR $(1+2+3)$ & 40.6 & "41.1 & 36.8 & 23.3 & 23.8 & 20.3 & 17.5 \\
\hline LFPR $(1+2+3+5)$ & 41.2 & 42.5 & 37.3 & 23.3 & 24.6 & 20.8 & 18 \\
\hline
\end{tabular}

Source: Abraham (2013).

Second, conflating participation in domestic activities with status production obscures the realities of rural working class and marginalized households in India. NSSO classifies 'domestic activities' into 'domestic activities only' and 'domestic and allied activities'. The latter constitutes unaccounted agricultural and allied activities, such as free collection of goods, preparation of cow dung cakes, domestic production and processing, fetching water. 'Domestic activities only' is assumed to consist of other invisible work that includes care work, cooking, and cleaning (Mukherjee, 2011). Women's participation in 'domestic activities only' increased from 15.1 to 18.5 percent between 1987-88 to 2011-12, but their participation in 'domestic and allied activities' increased from 12.2 to 23.7 percent in the same period (Table 3). While Figure 1 suggests a positive association between women's participation in 'domestic activities only' and household consumption expenditure, participation in 'domestic and allied activities' is negatively correlated with household consumption. Thus, we argue that characterizing all domestic activities as social 'status' production is unwarranted. 
Figure 1: Distribution of rural women's participation in domestic duties by MPCE deciles, 2011-12

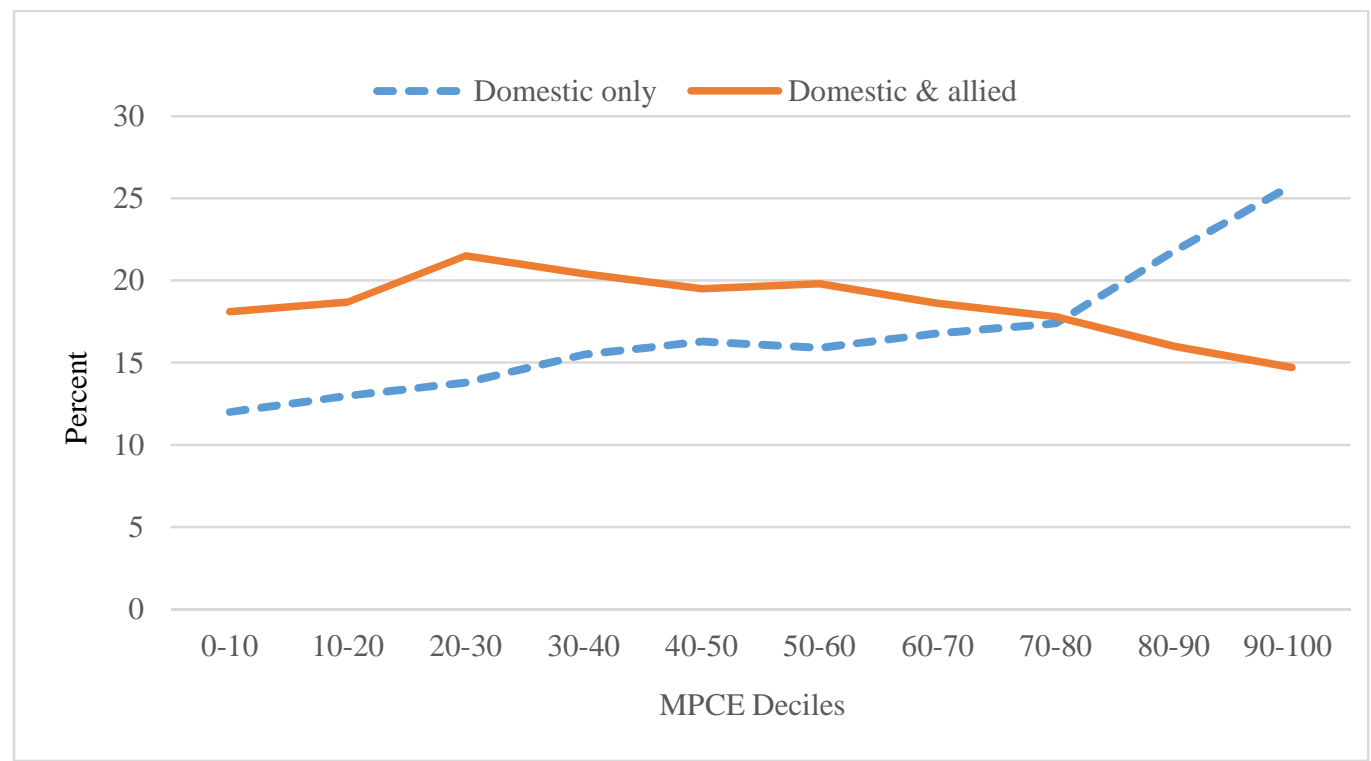

Source: (NSSO 2014a).

Note 1: $\mathrm{MPCE}=$ monthly per capital consumption expenditure of households.

Note 2: Data on activity status includes principal and subsidiary status.

Furthermore, Table 4 provides a breakdown of various activities undertaken by women participating in domestic and allied activities. The highest participation is in unaccounted agricultural production, free collection of goods, preparing cow dung, and fetching water, activities which have suitable market substitutes although they may be unaffordable to the working classes. According to the only National Time Use Survey conducted in 1998, ultra-poor women (who fall below the midpoint of the poverty line) spent 23.6 percent of their time on low-productivity subsistence work that is classified by NSSO as 'domestic and allied activities', whereas non-poor women (above the poverty line, but below the midpoint of average consumption expenditure of those above the poverty line) spent only 12.16 percent of their time on 'domestic and allied activities' (Hirway, 2010). While there are no recent national time use studies to compare the current situation, it is clear that domestic and allied activities are associated with low income and social status. In addition, the increase in income inequality between land-rich and land-poor households between 2003 and 2013 (Table 2), at the same time that which women's participation in domestic and allied activities increased from 18 to 23.7 percent, in 2004-05 to 2011-12 (Table 3), also suggests that working class households may be compensating for income differences across class by increasing time spent in non-capitalist subsistence production, thereby allowing 
them to compensate for the household income deficit. ${ }^{5}$ The withdrawal of women from the labour force and their increased participation in 'domestic and allied activities' may be an indicator of a reproductive crisis, rather than signifying social status or higher incomes.

Although subsistence production (domestic and allied activities) is not always carried out by women, it is overwhelmingly dominated by women because of structural constraints. About 60 percent of women above the age of 15 years responding to the NSS $68^{\text {th }}$ Round surveys noted that their primary occupation was domestic work because no one else would do the work, whereas only 15.8 percent cited religious and social constraints (NSSO, 2014c). This indicates (though does not confirm) the relevance of economic constraints and sexual division of labour in determining women's participation in domestic work instead of wage labour and other SNA activities.

Palriwala and Neetha (2009) attribute the crisis of consumption to inadequate labour commodification and 'familialism', which relies on family and community networks and reiterates the role of women's work in reproducing the household. The declining female LFPR in India may be a result of inadequate creation of high quality jobs, which has particularly impacted women workers (Das, 2006; Patnaik, 2003). While it has long been accepted that women constitute a significant proportion of the reserve army of labour (RAL), Table 4 provides evidence that this labour constitutes the latent or floating components of the RAL, and not the stagnant component engaged in status production and leisure activities, as suggested by some. It could be argued that state provisioning and wages are low because of 'familialism'. The direction of causality is, however, unclear. It is also possible that domestic economies (non-capitalist production) provide the only recourse to survival, given the lack of adequate jobs, wages, and social welfare measures. Rather than indicating a 'choice', or being a remnant of traditional societies, 'familialism' may reflect a constraint imposed by a neoliberal capitalism in which neither the market economy nor the state are willing to commit to reproducing working class households (see also Braedley, 2006). Increased participation in domestic and allied activities may thus reflect a coping mechanism to deal with the crisis of reproduction, which also provides a gendered subsidy to capital.

\footnotetext{
${ }^{5}$ See also Nathan and Kelkar (1999) for an analysis of the role of domestic economies after the Asian crisis.
} 
Table 4: Participation of women (15-59 years) usually engaged in domestic and allied activities (including subsidiary status) in 2011-12

\begin{tabular}{|l|r|}
\hline Specified activities & Rural (\%) \\
\hline Maintenance of kitchen garden (1) & 24.1 \\
Work in household poultry etc. (2) & 38 \\
Unaccounted agricultural \& allied activities (1or2) & 47.3 \\
Free collection of fish etc. (3) & 22.4 \\
Free collection of firewood, cattle fodder etc. (4) & 57.8 \\
Free collection of goods (3or4) & 59.8 \\
Food processing (own produce) (5) & 11.1 \\
Food processing (acquired) (6) & 6 \\
Preparing cow-dung cakes (7) & 56.3 \\
Sewing tailoring etc. (8) & 29.3 \\
Free tutoring of own and other's children (9) & 5.4 \\
Fetching water from outside house (10) & 40.4 \\
Fetching water from outside village (11) & 1 \\
\hline Women in this age and status category engaged in at & 89.5 \\
least one of the above activities & \\
\hline
\end{tabular}

Source: NSSO (2014c).

\section{Land, women's work and reproduction}

Figure 2 indicates that 15 to 20 percent of women from households across different levels of land cultivation participated in 'domestic and allied activities' in 2011-12. The non-linear relationship between the two variables suggests that women from 'effectively landless' households have a higher participation in 'domestic and allied' activities (see also Sen \& Sen, 1985). Land and 'domestic activities only' also display a non-linear relationship, in that participation in the latter is negatively associated with land as long as land cultivated is one hectare or less.

As Table 4 indicates, 59.8percent of women engaged in domestic and allied activities engaged in free collection of firewood and cattle fodder and 22.4 percent participated in free collection of fish and other food items, both of which require access to private or common lands. The blurring of perceived dichotomies between agrarian and environmental change has led to research that argues in favour of historical complementarity between agrarian livelihoods and private and common lands (Agrawal \& Sivaramakrishnan, 2000; MRD, 2009). Past literature suggests a non-linear 
relationship between land and free collection of goods (Narain et al., 2008). However, the rural land-poor are more dependent than the land-rich on free collection of goods from private and commons lands (Adhikari, 2005; Narain et al., 2008). Some studies have estimated that consumption of goods from common lands account for between nine to 26 percent of total rural household income, ${ }^{6} 91$ to 100 percent of total fuel requirements, and 69 to 89 percent of livestock feed requirements (Beck \& Ghosh, 1994; Jodha, 1986). We do not propose to extrapolate these results to all aspects of domestic and allied activities, but this literature compels us to recognize the relationship between land and women's work.

Figure 2: Distribution of rural women's participation in domestic duties by land cultivated, 2011-12

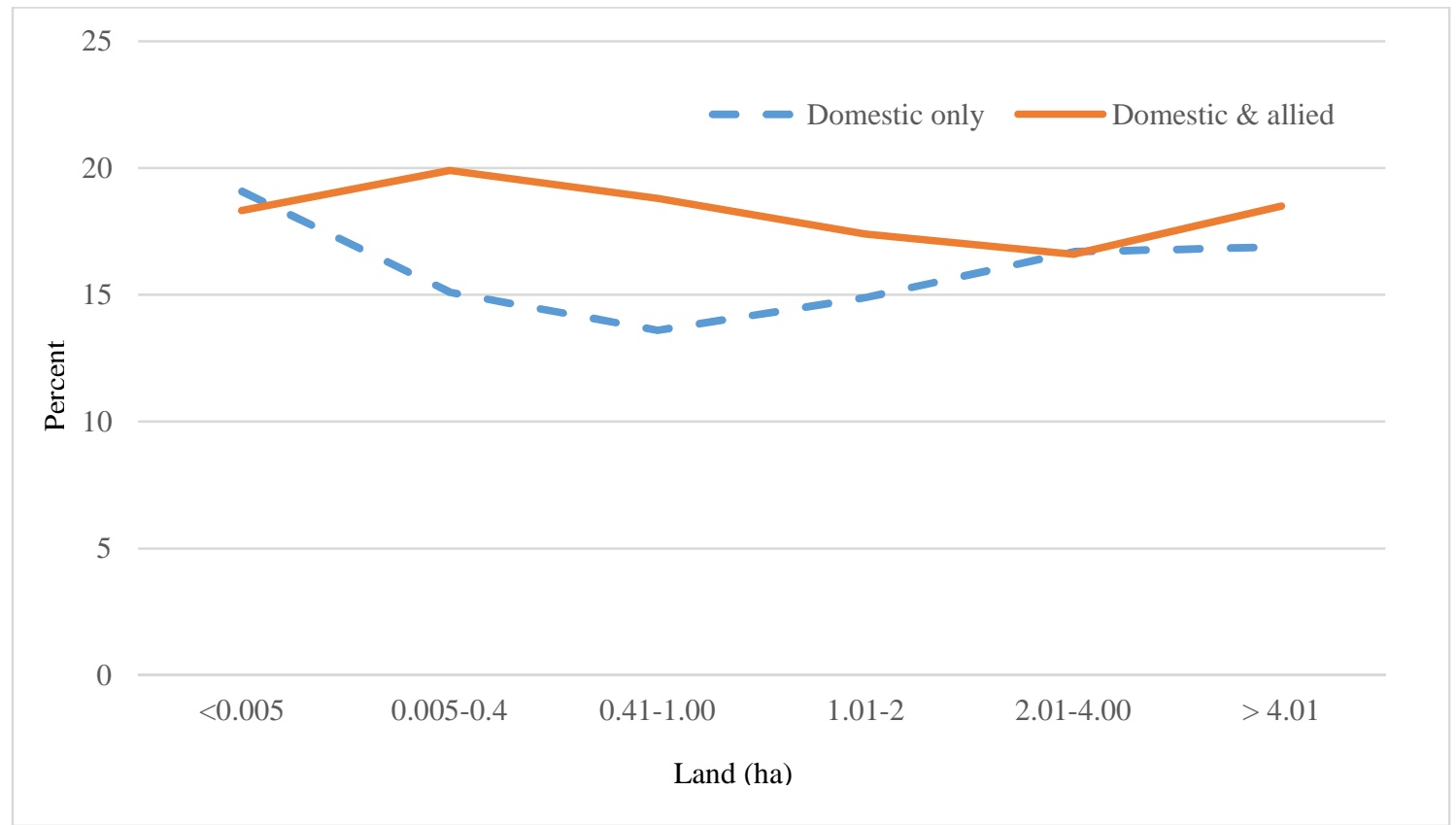

Source: NSSO (2014a).

Note: Data on activity status includes principal and subsidiary status.

\section{Land and its contemporary relevance}

Land reform has long been considered significant to rural development and poverty alleviation, but appears less relevant in the changed circumstances of the Indian and global economies. Yet,

\footnotetext{
${ }^{6}$ These figures are most likely lower bound estimates due to the limitations of assigning market-based exchange value to the use value of goods and services that do not pass through the market.
} 
its significance in relation to the crisis of reproduction - the expression of which is highly gendered by the fact that the bulk of the burden of reproduction is being shouldered by household labour performed mainly by women - cannot be gainsaid. The economic and social character of the subsidy afforded to capitalist accumulation by domestic economies asserts gender (the gendered characteristic of household reproduction) as a core and as yet unresolved variable of the contemporary agrarian question (Moyo, Jha \& Yeros, 2013). While domestic economies may have historically provided a wage subsidy, the attrition of such economies to land grabs, competition from international markets, and enclosure of forests and other natural resources makes such a subsidy less likely with the level of effort required prior to liberalization. It is in this context that we can understand the need for higher participation in domestic and allied activities. In the period 1987-88 to 2011-12, participation in domestic and allied activities jumped more than 10 percentage points. For women in 'effectively landless' households (less than 0.41 hectares), the category of domestic and allied work, which is labour intensive and invisible, keeps the highest proportion of women occupied. This suggests a positive complementarity between women's work, land (both common and private) and reproduction.

In 2004, 57 years after Independence, the Common Minimum Programme of the then ruling party re-stated its feeble commitment to land reforms by declaring that 'landless families will be endowed with land through implementation of land ceiling and redistribution legislation. No reversal of ceiling will be permitted' (cited in MRD, 2009). Unsurprisingly, however, nothing was actually done to fulfil land reforms. Instead, the Indian state has been either a silent spectator or an active facilitator in the dispossession of private and common lands from the marginalized. Combined with an inadequate wage economy, the dispossession from private and common lands has imposed an inordinately high burden of reproduction on households, especially women in these households.

Land also assumes significance in capitalist economic growth and this is evident in the massive transfers of land for mining, industrial, residential and commercial real estate and infrastructural projects. However, the resulting economic growth has not created an adequate number of jobs and well-paying jobs that would improve standards of living to justify the loss of traditional livelihoods. This has particularly affected women's labour force participation (Das, 2006; Ghosh, 
2009). De-peasantization thus does not guarantee proletarianization due to insufficient creation of secure well-paid jobs. Furthermore, the participation of the most vulnerable sections of rural India in the labour market may be a necessary, but not sufficient, condition for the reproduction of the rural labouring household, owing to labour flexibilization and deteriorating work conditions ]. Lacking their own means of production and combined with the poor state provisioning, rural Indian households are locked into an impoverishing cycle of poor quality jobs and low wages. The effects of this can only be borne by resorting to domestic economies, which is attracting high participation in the period after liberalization. Domestic economies, in turn, continue to be dependent on land. Of the domestic and allied activities for which NSSO collects data, the highest participation of women is in activities that directly or indirectly depend on either private or common lands.

The Ministry of Rural Development asserts that 'land reforms, including redistributive measures and security of tenure and ownership, prevention of usurious alienation from vulnerable segments of people and ownership of house sites' is essential to rid the country of rural poverty (MRD, 2009, p. [6]). It is, therefore, not surprising that despite the agricultural sector's declining share of GDP and employment, popular land struggles continue to dominate the Indian political landscape. In 2015, hundreds of farmers protested en masse, with tragic consequences, against the Indian state's proposed amendments to the Land Acquisition, Rehabilitation and Resettlement Act of 2013. While the working-class and the lower middle class bear the burden of supporting the stagnant form of RAL (Marx, 1986: 603), it is the yet non-commodified sphere of household subsistence production that supports the burden of reproducing the labour pool and the floating and latent forms of the RAL.

Feminist researchers have advocated for gender sensitive land reforms so that women's right to own and control land would combat patriarchy, feminization of poverty, and improve the bargaining and social position of women within and outside the household (Agarwal, 1997, 1994; Kelkar, 2013). It is only recently that there has been some improvement in furthering the rights of women to land in India. The 2005 amendment to the Hindu Succession Act of 1956 enlarges the rights (and liabilities) of married and unmarried daughters in the Hindu family, consonant with those of the male progeny of a coparcener. Notwithstanding contestations by male family members unwilling to part with their claims to the family inheritance, and women themselves willingly 
giving up their claims to avoid conflict and maintain cordial relations with their natal family, this legal amendment is fraught with larger problems, two of which are relevant to our discussion.

First, a large proportion of rural households in India are effectively landless (Basole \& Basu, 2011), and, hence, this legislation does not address their plight, nor that of women who are not born into Hindu families. This problem could be mitigated if women form agricultural cooperatives and purchase land and materials as a collective (Agarwal, 2010). However, this still raises the question of how initial capital would be raised, and does not offer a way out of neoliberal market-led agrarian reforms.

Second, the immiserating conditions suffered by the working classes, and particularly women from these classes, are not driven solely by a contextual patriarchy. Suggesting land reforms and women's right to land as a panacea to poverty reduction and empowerment ignores the realities of social relations of rural production and its articulation with the capitalist sector. Studies of the agrarian economy in India have suggested that class and ethnicity often supersede gender identities, that is, often women from upper class and castes are complicit in the economic exploitation of lower class, landless women (N. Rao, 2005; S. Rao, 2011). Thus, the amendment to the Hindu Succession Act does not serve to destabilize the agrarian class structure. The high incidence of subsistence production among land-poor households confronts us with the question of whether imperial capitalism is destroying traditional peasantries (Bernstein, 2004), or whether what we are witnessing is 'not the disappearance of the peasantry, but rather, its redefinition' (Johnson, 2004, p. 54). Given capitalism's tendencies towards 'involution' via its spatial concentration and centralization, matched by an expanding sphere of social exclusion, Johnson (2004, p. 63) adds:

The peasant form of production as operating according to a driving logic of subsistence and retaining at least some form of control over the means of production is not disappearing. Rather, it persists as rural populations are increasingly marginalized and impoverished by the currents of global capital. The persistence of the peasantry is not a positive process. It stands as a testament of the failures of the development project. 
Extending this argument to women's work, women's dependence on land for low-productivity and labour-intensive subsistence production to sustain domestic economies, while important to reproduction, is also cause for concern. It indicates the failure of the Indian economy to provide decent livelihoods. Women's increased participation in domestic economies is a result of contextually and historically determined patriarchy that works in tandem with neoliberal capitalism. Hence, land reforms that rely on individualist ontologies and which are concerned only with tenure security or land distribution may be insufficient for social transformation (Razavi, 2003).

Furthermore, as we have argued in this paper, gender inequity - which we address through an interrogation of reproductive labour - remains a contradiction to the peasant path to agrarian transformation. In other words, the prism of subsistence economies and the gendered labour regimes therein, which are highly predicated upon the free, exploitative, and self-exploitative labour performed by rural women on a daily basis, present the peasantry as a contradictory social force in the course of India's agrarian transformation. For even when gender is accounted for (normatively through guarantees of women's rights to land), this incorporation cannot proceed in isolation from the conditions of the global economy. That is, women might have land which they do not actually cultivate due to, for instance, insufficient support for agriculture and the failures or insufficiency of state provisioning. It may not be possible for women to escape the trap of poverty and immiseration simply because they have access to land. The failure to address the question of reproductive labour (the agrarian question of gendered labour) thus renders land reforms as incomplete. Ultimately, there is need to address the question of social reproduction.

In this regard, we view the failure of land and agrarian reforms in India as critical to understanding not only capitalism's exploitative tendencies in relation to women's reproductive labour, as argued in this paper, but also ironically, as a commentary on the continued relevance of land in the process of household reproduction. 


\section{Conclusion}

We have argued that the changing global conditions make it unlikely for land to lift the working classes out of poverty. Yet, land still affords the primary means of reproduction of rural households, a function which is still largely dependent on women's labour. This link - between the role of women's unpaid labour in reproducing rural households and the fact that this work remains largely dependent on land - reasserts gender equity as a contemporary and unresolved question in the midst of India's agrarian transition. The complexities and contradictions staged by neoliberal reforms means that neoliberal capitalist expansion ignores and undermines the reproductive aspects of land and women's labour, even as capitalist accumulation depends on them. The fact that reproduction relies on women's work further implies that household consumption is a function of a gender subsidy to capital. This subsidy traps women in their role in the reproductive household economy.

Ultimately our analysis makes visible two sets of issues that ought to be the focus of political demands: first, that land reform should address the gender inequities underlying women's invisible work, which entails making demands for structural changes that recognize the household sphere of reproduction through which gender becomes articulated to capitalist production; and second, that state intervention in both wages and households should be instituted at levels sufficient for reproduction, which otherwise continues to constitute a significant sphere of exploitation of women under capitalism.

\section{References}

Abraham, Vinoj (2013). Missing labour or consistent ‘de-feminisation'? Economic and Political Weekly, 48(31), 99-108.

Adhikari, Bhim (2005). Poverty, property rights and collective action: understanding the distributive aspects of common property resource management. Environment and Development Economics, 10, 7-31.

Agarwal, Bina (1994). A field of one's own: gender and land rights in South Asia. Cambridge: Cambridge University Press. 
Agarwal, Bina (1997). 'Bargaining' and gender relations: within and beyond the household. Feminist Economics, 3(1), 1-50.

Agarwal, Bina (2010). Rethinking agricultural production collectivities. Economic and Political Weekly, 45(9), 64-78.

Agrawal, Arun and K. Sivaramakrishnan (Eds) (2000). Agrarian environments: resources, representation, and rule in India. Durham, NC: Duke University Press.

Ahmed, Waquar and Ipsita Chatterjee (2013). Contradictory policies of neoliberalizing India. Human Geography, 6(2), 85-97.

Antonopolous, Rania and Indira Hirway (2010). Unpaid work and the economy: gender, time use and poverty in developing countries. New York, NY: Palgrave Macmillan.

Basole, Amit and Deepankar Basu (2011). Relations of production and modes of surplus extraction in India: Part I, Agriculture. Economic and Political Weekly, 46(15), 41-58.

Basole, Amit and Deepankar Basu (2012). The calorie consumption puzzle in India: an empirical investigation. Working Paper No. 285, Political Economic Research Institute, Amherst, MA.

Beck, Tony and M.G. Ghosh (2000). Common property resources and the poor: findings from West Bengal. Economic and Political Weekly, 35, 147-153.

Bernstein, Henry (2004). 'Changing before our very eyes': agrarian questions and the politics of land in capitalism today. Journal of Agrarian Change, 4(1-2), 190-225.

Braedley, Susan (2006). Someone to watch over you: gender, class and social reproduction. In Kate Bezanson and Meg Luxton (Eds), Social reproduction: feminist political economy challenges neo-liberalism. (pp. 215-230). Montreal: McGill-Queens Press.

Chopra, Deepta (2014). 'They don't want to work' versus 'they don't want to provide work': seeking explanations for the decline of MGNREGA in Rajasthan. ESID Working Paper No. 31, IDS, University of Sussex.

Cockcroft, James (1983). Immiseration, not marginalization: the case of Mexico. Latin American Perspectives, 10 (2/3), 86-107.

Das, Maitreyi Bordia (2006). Do traditional axes of exclusion affect labor market outcomes in India? South Asia Series, Paper No. 97. Washington DC: The World Bank.

Dev, S.M. (2008). Inclusive growth in India: agriculture, poverty and human development. New Delhi: Oxford University Press. 
Dickinson, James and Bob Russell (1985). The structure of reproduction in capitalist societies. In J. Dickinson and B. Russell (Eds), Family, economy and the state: social reproduction under capitalism. (pp. 1-19). New York, NY: St. Martin's Press.

Dreze, Jean and Reetika Khera (2009). The battle for employment guarantee. Frontline, 26(1), $3-$ 16.

Dutta, Puja, Rinku Murgai, Martin Ravallion and Dominique van de Walle (2012). Does India's employment guarantee scheme guarantee employment? Policy Research Paper 6003, The World Bank Development Research Group.

Ghosh, Jayati (2011). Cash transfers as the silver bullet for poverty reduction: a sceptical note. Economic and Political Weekly, XLVI, 67-71.

Gough, Ian (2004). Welfare regimes in development contexts: a global and regional analysis. In I. Gough, G. Wood, A. Barrientos, P. Bevan, P. Davis and G. Room (Eds), Insecurity and welfare regimes in Asia, Africa and Latin America. Social Policy in Development Contexts (pp.15-48). (pp. 15-48). Cambridge: Cambridge University Press:

Hirway, Indira (2010). Understanding poverty: insights emerging from time use of the poor. In R. Antonpolous and I. Hirway (Eds), Unpaid work and the economy: gender, time use and poverty in developing countries. (pp. 22-57). New York, NY: Palgrave Macmillan.

Jha, Raghbendra and Raghav Gaiha (2012). NREGS: interpreting the official statistics. Economic and Political Weekly, 47(40), 18-22.

Jha, Praveen (2009). The well-being of labour in contemporary indian economy: what's active labour market policy got to do with it? Employment Working Paper No. 39. Geneva: ILO.

Jodha, N.S. (1986). Common property resources and the rural poor in dry regions of India. Economic and Political Weekly, 21, 1169-1182.

Johnson, Heather (2004). Subsistence and control: the persistence of the peasantry in the developing world. Undercurrent, 1(1), 55-65.

Joshi, Varsha, Singh Surjit and K.N. Joshi (2008). Evaluation of NREGS in Rajasthan. Institute of Development Studies, Jaipur.

Kannan, K.P. and G. Raveendran (2012). Counting and profiling the missing labor force. Economic and Political Weekly, 47(6), 77-80.

Katz, Cindi (2001). Vagabond capitalism and the necessity of social reproduction. Oxford and Malden: Blackwell Publishers. 
Kelkar, Govind (2013). The fog of entitlement: women and land in India. Paper prepared for presentation at the annual World Bank Conference on Land and Poverty, Washington, DC, 8-11 April.

Khera, Reetika and Nandini Nayak (2009). Women workers and perceptions of the national employment guarantee act in India. Paper presented at the FAO-IFAD-ILO workshop on Gaps, Trends and Current Research in Gender Dimensions of Agricultural and Rural Employment: Differentiated Pathways out of Poverty, Rome, 31 March-2 April.

Lahoti, Rahui and Hema Swaminathan (2013). Economic growth and female labour force participation in India. Working Paper No. 414. India Institute of Management, Bangalore.

Luxemburg, Rosa (1951). The accumulation of capital. London: Routledge.

Marx, (1986). Capital: a critique of political economy. Volume one. Moscow: Progress Publishers.

Meillassoux, Claude 1977 Mujeres, graneros y capitales, Mexico City: Siglo XXI.

Mingione, Enzo (1985). Beyond employment: household, gender and subsistence. New York, NY: Blackwell.

Moyo, Sam, Praveen Jha and Paris Yeros (2013). The classical agrarian question: myth, reality and relevance today. Agrarian South: Journal of Political Economy, 2(1), 93-119.

Moyo, Sam and Paris Yeros (Eds) (2005). Reclaiming the land: the resurgence of rural movements in Africa, Asia and Latin America. London, New York, NY, \& Cape Town: Zed Books \& David Philip.

MRD (2009). Committee on state agrarian relations and unfinished task of land reforms. Volume 1: draft report. New Delhi: Ministry of Rural Development, Government of India.

Mukherjee, A. (2011). Exploring inter-state variations of rural women's paid and unpaid work in India. The Indian Journal of Labour Economics, 55(3), 371-392.

Nathan, Dev and Kelkar Govind (1999). Agrarian involution, domestic economy and women, Economic and Political Weekly, 34(19), 1135-1141.

Narain, U., S. Gupta and K. Van't Veld (2008). Poverty and the environment: exploring the relationship between household incomes, private assets, and natural assets. Land Economics, 84, 148-167. 
National Sample Survey Organization (NSSO) (2005). Income, expenditure and productive assets of farmer households. NSS round 59th. New Delhi: Ministry of Statistics and Programme Implementation, Government of India.

National Sample Survey Organization (NSSO) (2014a). Employment and unemployment situation in India. 68th Round, July 2011-June 2012. New Delhi: Ministry of Statistics and Programme Implementation, Government of India.

National Sample Survey Organization (NSSO) (2014b). Key indicators of situation of agricultural households in India. NSS 70 ${ }^{\text {th }}$ round, January-December 2013. New Delhi: Ministry of Statistics and Programme Implementation, Government of India.

National Sample Survey Organization (NSSO) (2014c). Participation of women in specified activities along with domestic duties. 68th round, July 2011-June 2012. New Delhi: Ministry of Statistics and Programme Implementation, Government of India.

Palriwala, Rajni and N. Neetha (2009). The care diamond: state social policy and the market. India Research Report 3. Geneva: UNRISD.

Pankaj, Ashok (2008). Processes, institutions, and mechanisms of implementation of NREGA: impact assessment of Bihar and Jharkhand. New Delhi: Ministry of Rural Development, Government of India and UNDP, Institute for Human Development.

Pankaj, Ashok and Tankha Rukmini (2009). Women's empowerment through guaranteed employment: a case study of NREGA implementation in Bihar, Jharkhand, Rajasthan, and Himachal Pradesh. New Delhi: UNIFEM, Institute for Human Development.

Patnaik, Utsa (2003). Global capitalism, deflation and agrarian crisis in developing countries. In S. Razavi (Ed), Agrarian change, gender and land rights. (pp. 33-66). Oxford: Blackwell Publishing Ltd.

Rao, Nitya (2005). Questioning women's solidarity: the case of land rights in Santal Parganas. Journal of Development Studies, 41(3), 353-375.

Rao, Smriti (2011). Work and empowerment: women and agriculture in South India. Journal of Development Studies, 47(2), 294-315.

Ravi, Shamika and Monika Engler (2013). Workfare as an effective way to fight poverty: the case of India's NREGS. Retrieved form http://ssrn.com/abstract=1336837

Razavi, Shahra (Ed) (2003). Agrarian change, gender and land rights. Oxford: Blackwell Publishing Ltd. 
RBI (2005). State finance: a study of budgets, 2004-05. Mumbai: Reserve Bank of India.

RBI (2015). State finance: a study of budgets, 2014-15. Mumbai: Reserve Bank of India.

Sainath, P. (2010). Farmer suicides: a 12-year saga. The Hindu, 1 February 2010. Retrieved from http://www.thehindu.com/opinion/columns/sainath/farm-suicides-a-12year$\underline{\text { saga/article94324.ece }}$

Shah, Alpa and Barbara Harris-White (2011). Resurrecting scholarship on agrarian transformations. Economic and Political Weekly, 46(39), 13-18.

Sen, Gita and Chiranjib Sen (1985). Women's domestic work and economic activity: results from the national sample survey. Economic and Political Weekly, 20(17), WS49-WS56.

Thomas, Jayan Jose (2014). The demographic challenge and employment growth in India. Economic and Political Weekly, 49(6), 15-17.

Vakulabharanam, Vamsi (2010). Does class matter? Class structure and worsening inequality in India. Economic and Political Weekly, 45(29), 67-76.

WDI (2014). World development indicators. Washington, DC: World Bank. 